\title{
Dioctophyme renale (Nematoda: Dioctophymatidae) in Leopardus geoffroyi (Carnivora: Felidae) in the Neotropical region
}

\author{
Dioctophyme renale (Nematoda: Dioctophymatidae) em Leopardus geoffroyi (Carnivora: Felidae) na região \\ Neotropical
}

Maira Aparecida Christello Trindade*; Marcia Raquel Pegoraro de Macedo'; Gertrud Muller ${ }^{1}$

\begin{abstract}
${ }^{1}$ Laboratório de Parasitologia de Animais Silvestres, Departamento de Microbiologia e Parasitologia, Instituto de Biologia - IB, Universidade Federal de Pelotas - UFPel, Pelotas, RS, Brasil
\end{abstract}

Received October 19, 2017

Accepted November 27, 2017

\begin{abstract}
Parasitic diseases affecting wild carnivores remain largely unknown or poorly described. Dioctophymosis is a parasitosis caused by the nematode Dioctophyme renale that is found worldwide. It affects domestic and wild animals and has been reported frequently in Brazil. This paper reports dioctophymosis in a wild felid for the first time.
\end{abstract}

Keywords: Dioctophymosis, wild felid, kidney, urban area, Brazil.

\section{Resumo}

As doenças parasitárias que acometem os carnívoros silvestres ainda são desconhecidas ou pouco descritas. A dioctofimatose, parasitose de distribuição mundial causada pelo nematoide Dioctophyme renale, acomete animais domésticos e silvestres e tem sido relatada com frequência no Brasil. Este estudo reporta o primeiro caso de dioctofimatose em um felídeo silvestre.

Palavras-chave: Dioctofimatose, felídeo silvestre, rim, área urbana, Brasil.

Dioctophyme renale Goeze, 1782, the giant kidney worm as it is popularly known, parasites the urinary tracts of mammals (Canidae and Mustelidae) and acidentally humans (ANDERSON, 2000). The life cycle of $D$. renale is indirect, and its intermediate host is the aquatic annelid Lumbriculus variegatus Müller, 1774. This species has been identified both experimentally and naturally as an intermediate host (MACE \& ANDERSON, 1975) in North America and was recorded in Patagonia by Miserendino (2007), and in the State of Minas Gerais, Brazil, by Marchese et al. (2015). The definitive hosts are infected by ingesting annelid with third-stage larvae or by ingesting paratenic hosts, such as fish and amphibians (MACE \& ANDERSON, 1975; MEASURES \& ANDERSON, 1985).

This paper reports the wild felid Leopardus geoffroyi d'Orbigny \& Gervais 1844 , as a new host to D. renale in the Neotropical region.

An adult female of L. geoffroyi was found dead due to being run over (i.e the specimen was roadkill) in the municipality of Capão do Leão (31 45’ 07.3” S; 520 25’ 19.3” W), in the south of the state of Rio Grande do Sul, Brazil, in July 2017. The carcass was collected (ICMBio/no. 389133) and sent to the Laboratory

*Corresponding author: Maira Aparecida Christello Trindade. Departamento de Microbiologia e Parasitologia, Instituto de Biologia - IB, Universidade Federal de Pelotas - UFPel, Campus Universitário Capão do Leão, CP 354, CEP 96010-900, Pelotas, RS, Brasil. e-mail: maira.263@hotmail.com for Parasitology of Wild Animals, Federal University of Pelotas, for parasitological investigation.

Through the necropsy, a male specimen ${ }^{\dagger}$ of $D$. renale was found in the right kidney of the host (Figure 1). Upon macroscopic examination, the parasitized kidney was fibrous and deformed. We could not find any lesions or $D$. renale in the left kidney or in any other inspected organs. The specimen, of length $19 \mathrm{~cm}$, had morphological characteristics compatible with those reported by Anderson (2000) for D. renale: a fleshy bell-shaped copulatory bursa, without any supporting rays, and a single bristle-like spicule.

Although this nematode is commonly found in the right kidney (NAKAGAWA et al., 2007) or free in the abdominal cavity of the definitive hosts, the reasons for its preference for this organ remain unclear. Atypical sites have been described in the stomach and bladder (MIRANDA et al., 1992), testes (REGALIN et al., 2016), mammary glands and inguinal region (PEREIRA-FIGUEIREDO et al., 2013) and spine (BACH et al., 2016).

Occurrence of a single parasite in the host is common, but high-intensity infections have also been reported. In Uruguaiana, a city located in the western region of Rio Grande do Sul - Brazil,

\footnotetext{
The specimen was deposited in the Coleção Helmintológica of the Laboratório de Parasitologia de Animais Silvestres, Instituto de Biologia, Universidade Federal de Pelotas (CHLAPASIL/UFPel), under the number 695.
} 

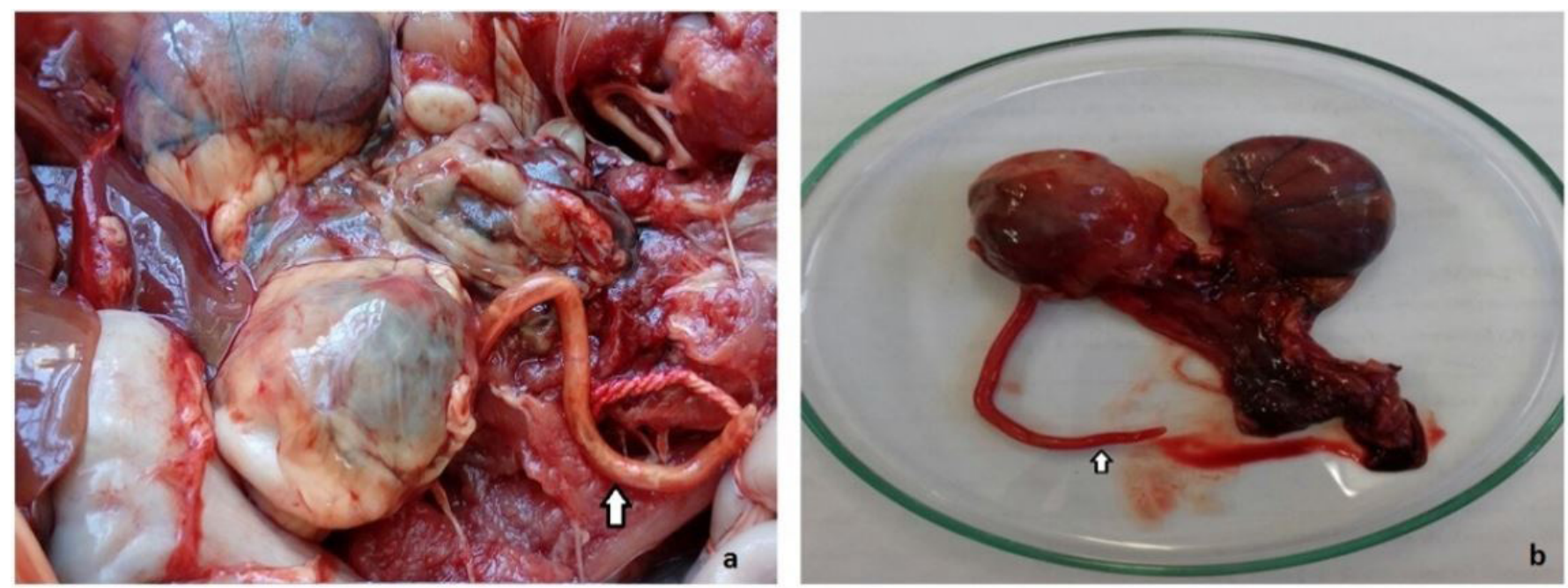

Figure 1. (a, b) Adult male of Dioctophyme renale (arrowed), found in right renal capsule.

34 specimens were found in a male dog (MONTEIRO et al., 2002). Perera et al. (2017) found 23 specimens in a female dog in Pelotas (RS, Brazil) and, in the state of Santa Catarina - Brazil, Pedrassani et al. (2014) reported finding two specimens in a female cat: one in the abdominal cavity and another in a supernumerary kidney.

In a study conducted in Pelotas, Rappeti et al. (2017) recorded 92 cases of dioctophymosis in domestic dogs and only three cases in cats, found through necropsy (from 1981 to 2014) and by using ultrasound examination (from 2010 to 2015). The majority of the infected animals are asymptomatic, even if the parasitized kidney has been totally destroyed (MEASURES, 2001). However, in some cases, clinical manifestations such as dysuria, hematuria, and backache are observed (PERERA et al., 2017).

In Brazil, $D$. renale parasitism has been described mainly in canids and mustelids (BARROS et al., 1990; KOMMERS et al., 1999; ZABOTT et al., 2012; VULCANI et al., 2015) but other wild mammals were reported harboring the parasite: Cebus apella (tufted capuchin) (ISHIZAKI et al., 2010), Choloephus didactylus (southern two-toed sloth) (ROCHA, et al., 1965), and Nasua nasua (ring-tailed coati) (MILANELO et al., 2009). Those reports suggest that $D$. renale exhibits low host specificity.

The disease in dogs may be associated not only with consumption of potential paratenic hosts but also with consumption of water from ditches: free-ranging urban dogs are unselective in their feeding habits (BURGOS et al. 2014). Because of cat's strong hunting instincts (and especially so among feral cats), they may well become infected by consuming fish and amphibians (VEROCAI et al., 2009). In Pelotas, third-stage larvae were found encysted in turtles (Trachemys dorbigni) and in freshwater fish (Hoplosternum littorale). From the 32 specimens of T. dorbigni analyzed, $87.5 \%$ were infected. These reports alert to the situation of the municipality in relation to parasitosis (MASCARENHAS \& MÜLLER, 2015; MASCARENHAS et al., 2016).

The finding of $D$. renale in $L$. geoffroyi corroborates the affirmations of Rappeti et al. (2017), i.e that this region is an ideal environment with the conditions necessary for development and maintenance of the disease. The felid examined here was found in an urban environment in the municipality Capão do Leão, which borders on Pelotas.

The high rates of natural infection among domestic animals and finds in wild animals in the southern region of the State of Rio Grande do Sul serve as a warning of the risks to public health, given that this parasite has zoonotic potential. Although found with low prevalence, occurrences in humans have been recorded in Asia and Europe (KATAFIGIOTIS et al., 2013; NOROUZI et al., 2017). Only one case of human infection in Brazil was documented in 1945 in the State of Maranhão (PAVANELLI et al., 2015).

Despite significant increased published reports of dioctophymosis in Brazil, the epidemiological cycle of this parasite remains unclear. This makes it evident that there is a need for studies concerning the parasite's biology and a need for prompt notifications in cases of diseased domestic and wild animals. This was the first record of Dioctophyme renale in a Neotropical felid.

\section{Acknowledgements}

We are grateful to Coordenação de Aperfeiçoamento de Pessoal de Nível Superior (CAPES) for its financial support (Edital 32/2010).

\section{References}

Anderson RC. Nematode parasites of vertebrates: their development and transmission. London: CABI International; 2000.

Bach FS, Klaumann PR, Montiani-Ferreira F. Paraparesis secondary to erratic migration of Dioctophyma renale in a dog. Cienc Rural 2016; 46(5): 885-888. http://dx.doi.org/10.1590/0103-8478cr20151219.

Barros DM, Lorini ML, Persson VG. Dioctophymosis in the little grison (Galictis cuja). J Wildl Dis 1990; 26(4): 538-539. PMid:2250331. http:// dx.doi.org/10.7589/0090-3558-26.4.538.

Burgos L, Acosta RM, Fonrouge RD, Archelli SM, Gamboa MI, Linzitto OR, et al. Prevalence of a zoonotic parasite, Dioctophyma renale (Goeze, 1782), among male canines in a wild riverside area of La Plata River, 
Province of Buenos Aires, Republic of Argentina. Rev Patol Trop 2014; 43(4): 420-426.

Ishizaki MN, Imbeloni AA, Muniz JAPC, Scalercio SRRA, Benigno RNM, Pereira WLA, et al. Dioctophyma renale (Goeze, 1782) in the abdominal cavity of a capuchin monkey (Cebus apella), Brazil. Vet Parasitol 2010; 173(3-4): 340-343. PMid:20691541. http://dx.doi.org/10.1016/j. vetpar.2010.07.003.

Katafigiotis I, Fragkiadis E, Pournaras C, Nonni A, Stravodimos KG. A rare case of a 39 year old male with a parasite called Dioctophyma renale mimicking renal cancer at the computed tomography of the right kidney. A case report. Parasitol Int 2013; 62(5): 459-460. PMid:23811203. http:// dx.doi.org/10.1016/j.parint.2013.06.007.

Kommers GD, Ilha NRS, Barros CSL. Dioctofimose em cães: 16 casos. Cienc Rural 1999; 29(3): 517-522. http://dx.doi.org/10.1590/S010384781999000300023.

Mace TF, Anderson RC. Development of the giant kidney worm, Dioctophyma renale (Goeze, 1782) (Nematoda: Dioctophymatoidea). Can J Zool 1975; 53(11): 1552-1568. PMid:127653. http://dx.doi. org/10.1139/z75-190.

Marchese MR, Santos MR, Lima JCS, Pamplin PAZ. First record of introduced species Lumbriculus variegatus Müller, 1774 (Lumbriculidae, Clitellata) in Brazil. BioInvasions Rec 2015; 4(2): 81-85. http://dx.doi. org/10.3391/bir.2015.4.2.02.

Mascarenhas CS, Henzel ABD, Corrêa F, Robaldo RB, Müller G. Thirdstage larvae of Dioctophyme renale (Goeze, 1782) (Nematoda: Enoplida) in Hoplosternum littorale (Hancock, 1828) (Siluriformes: Callichthyidae) from southern Brazil. Neotrop Helminthol 2016; 10(1): 135-138.

Mascarenhas CS, Müller G. Third-stage larvae of the enoplid nematode Dioctophyme renale (Goeze, 1782) in the freshwater turtle Trachemys dorbigni from southern Brazil. J Helminthol 2015; 89(5): 630-635. PMid:24830883. http://dx.doi.org/10.1017/S0022149X14000364.

Measures LN, Anderson RC. Centrarchid fish as paratenic hosts of the giant kidney worm, Dioctophyma renale (Goeze, 1782), in Ontario, Canada. J Wildl Dis 1985; 21(1): 11-19. PMid:3157009. http://dx.doi. org/10.7589/0090-3558-21.1.11.

Measures LN. Dioctophymatosis. In: Samuel WM, Pybus MJ, Kocan AA. Parasitic diseases of wild mammals. 2nd ed. Iowa: Iowa State University Press; 2001. p. 357-364.

Milanelo L, Moreira MB, Fitorra LS, Petri BSS, Alves M, Santos AC. Occurrence of parasitism by Dioctophyma renale in ring-tailed coatis (Nasua nasua) of the Tiete Ecological Park, São Paulo, Brazil. Pesq Vet Bras 2009; 29(12): 959-962. http://dx.doi.org/10.1590/S0100-736X2009001200001.

Miranda MA, Benigno RNM, Galvão GR, Oliveira SAL. Dioctophyme renale (Goeze, 1782): Localização ectópica e alta intensidade parasitária em Canis familiaris do Pará - Brasil. Arq Bras Med Vet Zootec 1992; 44(2): 151-153.
Miserendino ML. Macroinvertebrate functional organization and water quality in a large arid river from Patagonia (Argentina). Ann Limnol 2007; 43(3): 133-145. http://dx.doi.org/10.1051/limn:2007008.

Monteiro SG, Sallis ESV, Stainki DR. Infecção natural por trinta e quatro helmintos da espécie Dioctophyma renale (Goeze, 1782) em um cão. Rev FZVA 2002; 9(1): 95-99.

Nakagawa TLDR, Bracarense APFRL, Reis ACF, Yamamura MH, Headley SA. Giant kidney worm (Dioctophyma renale) infections in dogs from northern Paraná, Brazil. Vet Parasitol 2007; 145(3-4): 366370. PMid:17156927. http://dx.doi.org/10.1016/j.vetpar.2006.10.027.

Norouzi R, Manochehri A, Hanifi M. A case report of human infection with Dioctophyma renale from Iran. Urol J 2017; 14(2): 3043-3045. PMid:28299768.

Pavanelli GC, Eiras JC, Yamaguchi MU, Takemoto RM., organizadores. Zoonoses humanas transmissiveis pelos peixes no Brasil. Maringá: UniCesumar; 2015.

Pedrassani D, Wendt H, Rennau EA, Pereira ST, Wendt SBT. Dioctophyme renale Goeze, 1782 in a cat with a supernumerary kidney. Rev Bras Parasitol Vet 2014; 23(1): 109-111. PMid:24728372. http://dx.doi.org/10.1590/ S1984-29612014018.

Pereira-Figueiredo MA, Franco-da Silva D, Gómez- Manrique W, Rodriguesde Sousa AA. Cycle erratic Dioctophyme renale: report of two cases. Orinoquia 2013; 17(1): 96-101. http://dx.doi.org/10.22579/20112629.54.

Perera SC, Rappeti JCS, Milech V, Braga FA, Cavalcanti GAO, Nakasu $\mathrm{CC}$, et al. Eliminação de Dioctophyme renale pela urina em canino com dioctofimatose em rim esquerdo e cavidade abdominal - Primeiro relato no Rio Grande do Sul. Arq Bras Med Vet Zootec 2017; 69(3): 618-622. http://dx.doi.org/10.1590/1678-4162-9036.

Rappeti JCS, Mascarenhas CS, Perera SC, Müller G, Grecco FB, Silva LMC, et al. Dioctophyme renale (Nematoda: Enoplida) in domestic dogs and cats in the extreme south of Brazil. Rev Bras Parasitol Vet 2017; 26(1): 119-121. PMid:27925066. http://dx.doi.org/10.1590/s1984-29612016072.

Regalin BDC, Tocheto R, Colodel MM, Camargo MC, Gava A, Oleskovicz N. Dioctophyma renale em testículo de cáo. Acta Sci Vet 2016; 44(S1): 148.

Rocha UF, Serra RG, Grechi R. Parasitismo por Dioctophyme renale (Goeze, 1782) em 'preguica' Choloepus didactylus Linnaeus, 1758. Rev Farm Bioquim Univ São Paulo 1965; 3(2): 325-334.

Verocai GG, Measures LN, Azevedo FD, Correia TR, Fernandes JI, Scott FB. Dioctophyme renale (Goeze, 1782) in the abdominal cavity of a domestic cat from Brazil. Vet Parasitol 2009; 161(3-4): 342-344. PMid:19285807. http://dx.doi.org/10.1016/j.vetpar.2009.01.032.

Vulcani VAS, Franzo VS, Araújo DP, Vicentin FR, Costa OM, Rangel AS, et al. Dioctophyma renale em Lobo-Guará na região geoeconômica de Jataí, GO, Brasil - relato de caso. Rev Bras Med Vet 2015; 37(2): 149-152.

Zabott MV, Pinto SB, Viott AM, Tostes RA, Bittencourt LHFB, Konell AL, et al. Ocorrência de Dioctophyma renale em Galictis cuja. Pesq Vet Bras 2012; 32(8): 786-788. http://dx.doi.org/10.1590/S0100736X2012000800018. 